\title{
Analysis of Factors Related to the Head of Nurses in the Implementation of Prevention and Control of Infections in Hospital
}

\author{
Serri Hutahaean*, Nourmayansa Vidya Anggraini**, Dosmaida Nababan*** \\ *M Author Correspondence: serrihthyn@upnvj.ac.id \\ * Faculty of Health Sciences UPN "Veteran" Jakarta, Indonesia \\ **Faculty of Health Sciences UPN "Veteran" Jakarta, Indonesia \\ ***Nursing Academi Institute of Health Science Arjuna Indonesia
}

\begin{tabular}{l}
\hline I N D E X I N G \\
\hline Keywords: \\
Factors; \\
Nurse Compliance; \\
Implementation;
\end{tabular}

Implementation;

Kata kunci:

Faktor-faktor;

kepatuhan perawat; penerapan;

\begin{abstract}
A B S T R AC T
The problem of infection in nursing services in hospital and in health care facilities is that Healthcareassociated infections are still high. The compliance rate in implementing Infection Prevention and Control is still low. Nurses' non-compliance with Infection Prevention and Control implementation can be found in the ward with a variety of causative factors. This study aims to analyze the factors associated with nurse compliance in implementing infection prevention and control in hospital. The method used was quantitative research with cross sectional design. The respondents consisted of 34 implementing nurses at hospital $\mathrm{X}$ in Jakarta. The results showed a significant relationship between nurses 'knowledge (pv 0.01; $\alpha$ 0.05), motivation, (pv 0.04; $\alpha$ 0.05) and nurses' perceptions (pv 0.02; $\alpha$ 0.05) on adherence Infection Prevention and Control implementation, but there is no relationship between attitude factor with the implementation of Infection Prevention and Control (pv 0.51; $\alpha$ 0.05 ). It is suggested that the support of nursing management, the head of room and service providers are needed to improve nurses' compliance with the implementation of Infection Prevention and Control as a basis for improving the quality of nursing services in hospitals through increasing the knowledge, motivation and perceptions of nurses in the provision of facilities and infrastructure in infection prevention and control.
\end{abstract}

\begin{abstract}
Masalah infeksi dalam layanan keperawatan di rumah sakit dan di fasilitas perawatan kesehatan adalah infeksi terkait Layanan Kesehatan masih tinggi. Tingkat kepatuhan dalam menerapkan Pencegahan dan Kontrol Infeksi masih rendah. Ketidakpatuhan perawat dengan penerapan Pencegahan dan Pengendalian Infeksi dapat ditemukan di bangsal dengan berbagai faktor penyebab. Penelitian ini bertujuan untuk menganalisis faktor-faktor yang terkait dengan kepatuhan perawat dalam menerapkan pencegahan dan pengendalian infeksi di rumah sakit. Metode yang digunakan adalah penelitian kuantitatif dengan desain cross sectional. Responden terdiri dari 34 perawat pelaksana di rumah sakit $X$ di Jakarta. Hasil penelitian menunjukkan hubungan yang signifikan antara pengetahuan perawat ( $p v 0,01 ; \alpha 0,05)$, motivasi, ( $p v 0,04 ; \alpha 0,05)$ dan persepsi perawat ( $p v$ 0,$02 ; \alpha$ 0,05) tentang kepatuhan Pencegahan Infeksi dan implementasi pengendalian, tetapi tidak ada hubungan antara faktor sikap dengan penerapan Pencegahan dan Kontrol Infeksi (pv 0,51; $\alpha$ 0,05). Disarankan bahwa dukungan manajemen keperawatan, kepala kamar dan penyedia layanan diperlukan untuk meningkatkan kepatuhan perawat dengan pelaksanaan Pencegahan dan Kontrol Infeksi sebagai dasar untuk meningkatkan kualitas layanan keperawatan di rumah sakit melalui peningkatan pengetahuan, motivasi dan persepsi perawat dalam penyediaan fasilitas dan infrastruktur dalam pencegahan dan pengendalian infeksi.
\end{abstract}

(C) 2019 JMMR. All rights reserved

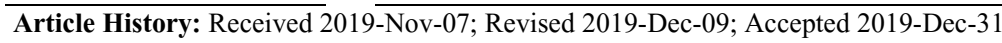

\section{INTRODUCTION}

The problem of infection in nursing services in hospitals and health care facilities (Healthcare-associated infections/HAIs) is still high. It is estimated that 1 out of 25 hospital patients has at least 1 type of HAIs every day. ${ }^{1}$ Infections that occur in hospitals are at least around $9 \%$ (variation 3-21\%) of more than 1.4 million inpatients in hospitals throughout the world. ${ }^{2}$ The research in Poland which was reported by Deptula, found that the infection rate was $17.5-30.2 \%$. In Indonesia itself, information about the incidence of infection in BLU Prof. Dr. DR. RD Kandou Manado was $0.7-3.4 \%$ and at Santo Yusuf Hospital Bandung was $0.10-3.13 \% .^{3.4}-$ The survey results at the Siaga Raya Hospital, Jakarta, in November 2016 
showed that the infection rate was $1.1-24.6 \%$. The variation or the high number of infections can have a negative impact on the health sector, especially in nursing services that directly provide care to clients. Nurse compliance in implementing Inter Professional Collaboration (IPC) is needed.

Nurse compliance rates in implementing IPC are still low. The hand hygiene compliance rate is $22-60 \%$ according to WHO. -5 As many as $41 \%$ of nurses said they never wear masks when there is a risk of infectious diseases through the air, and $44 \%$ say they never wear gloves when taking action with patients. ${ }^{-}$Lack of compliance rates in the use of personal protective equipment (PPE) resulted in the incidence of injury to sharps (such as syringes) $21.5 \%$, injuries and scratches $17.0 \%$, direct contact with contaminated specimens $10.5 \%$, air infections $9.0 \%$. Tung, Chang, Ming, \& Chao, found that $42.9 \%$ of nurses suffered sharp object injuries resulting from not wearing gloves when taking action..$^{-}$Many things affect nurses' compliance in infection prevention and control.

Nurse non-compliance in IPC can be found in the ward with a variety of causative factors. Factors causing nurses 'noncompliance in the implementation of IPC are lack of IPC implementation time, forgetful factors, lack of IPC infrastructure, equipment that is less comfortable to use, can cause skin irritation, where infrastructure facilities are less supportive, lack of nurses' understanding of the conflict between IPC implementation needs and care and nurse's self-protection, lack of training. ${ }^{9}$ Nurse compliance in IPC implementation is still influenced by other factors.

Other factors that influence nurses' compliance in the implementation of IPC can be influenced by leader factors in the ward. The lack of role of clinic leaders in the ward in teaching IPC can result in a lack of nurse expertise in implementing IPC. $\stackrel{10}{ }$ Besides, funding and technology factors that do not support, supervision and auditing that are lacking from the leadership, decreasing the resistance of leadership activity in supporting nurses doing IPC greatly affect nurses' disobedience in IPC implementation. ${ }^{11}$ The causes of lack of compliance in implementing IPC can be reduced by various efforts to implement IPC.

In order to overcome the causes of non- compliance in the implementation of IPC, planning, implementation, coaching, education and training, as well as monitoring and evaluation are neede. This is supported explaining that infection control programs through staff education about measures to reduce the risk of contamination, especially hand washing, proper disposal of infectious waste, and strict asepsis during procedures, as well as wise use of antibiotics has been shown to reduce substantially the incidence of septicemia and infant mortality in Bangladesh. ${ }^{12}$ infection prevention is a key role for all health professionals, including nurses. Infection prevention must be supported by an understanding of the process of spreading infection by adhering to strategies that promote infection control. $\frac{13}{}$

\section{RESEARCH METHOD}

This research was conducted at Siaga Raya Hospital in Jakarta. The sampling method in this study uses a purposive sampling method. The sample of this study was 34 implementing nurses. This research is a survey research with a quantitative approach. The design of this research is cross-sectional. This research was conducted on May 2017. The research instrument used a questionnaire. This study was conducted to analyze the factors that influence compliance in the implementation of IPC nurse at the hospital.

\section{RESULTS AND DISCUSSION}

The results of this study are known to the characteristics of Hospital X nurses who carry out infection prevention and control. These characteristics include gender, education level, age, and years of service in the form of frequency distributions as in tables 1 . and table 2 .

Table 1. Characteristics of nurses based on sex, education level of nurses implementing at the hospital

\begin{tabular}{lcc}
\hline \multicolumn{1}{c}{ Variable } & Frequency & \% \\
\hline Gender & & \\
Male & 1 & 2.95 \\
Girl & 33 & 97.05 \\
Level of education & & \\
D3 & 31 & 91.17 \\
S1 & 1 & 2.94 \\
Ners & 2 & 5.89 \\
\hline
\end{tabular}

Interpretation based on table 1 shows the characteristics of nurses based on gender are more female, namely as many as 33 people $(97.05 \%)$. Most respondents have a D3 education level of 31 people $(91.17 \%)$.

Table 2. Characteristics of nurses based on age and length of service of nurses in hospital, May $2017(n=34)$

\begin{tabular}{lrccc}
\hline $\mathbf{V}$ & $\mathbf{T m}$ & $\mathbf{E S}$ & $\mathbf{S E}$ & $\mathbf{( C I )} \mathbf{9 5 \%}$ \\
\hline Age & 28.03 & 5.73 & 0.98 & $28.82 ; 31.71$ \\
Years of service & 6.15 & 6.02 & 1.03 & $7.80 ; 8.23$ \\
\hline
\end{tabular}

Note: (V: Variabel, Tm: The mean, ES: Elementary school) 
Interpretation based on table 2 shows the average age of nurses 28.03 with a standard deviation of 5.73 years. The results of the estimation interval can be concluded that $95 \%$ believed that the average age of nurses is between 28.82 up to 31.71 years. The average work period of nurses is 6.15 with a standard deviation of 6.02 years. At the level of confidence of $95 \%$ is believed to past work of nurses is between 7.80 until the $8: 23$ year.

Factors of Knowledge, Attitudes, Motivations, Nurse Perceptions of Infrastructure Facilities

Data with numerical data namely knowledge, attitudes, motivation and perceptions of nurses can be seen in tables 3 and 4 :

Table 3. Nurse knowledge, May $2017(n=34)$

\begin{tabular}{lccc}
\hline Variable & $\begin{array}{c}\text { The } \\
\text { mean }\end{array}$ & $\begin{array}{c}\text { Elementary } \\
\text { school }\end{array}$ & $\boldsymbol{S E}$ \\
\hline Knowledge & 11.21 & 1.40 & 0.24 \\
Attitude & 3.05 & 0.50 & 0.08 \\
Motivation & 3.05 & 0.54 & 0.09 \\
Nurse's perception & 3.02 & 0.55 & 0.09 \\
of infrastructure & & & \\
\hline
\end{tabular}

Interpretation based on table 3 shows the average knowledge of nurses about the implementation of IPC is good that is as much as $11.21(80.07 \%)$. The average attitude of nurses towards the implementation of IPC is not good, which is $3.05(25.42 \%)$. The average motivation of nurses towards implementing IPC is as good as $3.05(61 \%)$. The average of nurses' perceptions of infrastructure in implementing IPC was good, namely 3.02 (50.33\%).

Table 4. Nurse Knowledge, May $2017(n=34)$

\begin{tabular}{ccc}
\hline Variable & $\mathbf{p}$-Value & Information \\
\hline Knowledge & 0.01 & There is a relationship \\
Attitude & 0.51 & No connection \\
Motivation & 0.04 & There is a relationship \\
Perception & 0.02 & There is a relationship \\
\hline
\end{tabular}

The interpretation is based on Table 4 shows that the knowledge of factors known to exist a relationship between nurse's knowledge of the implementation of IPC with p-

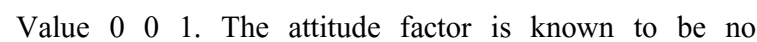
relationship between nurses' attitudes towards the implementation of IPC with p-velue 0.51. Factor motivation note there is a relationship between motivation nurses on the implementation of IPC with p-Value 0:04. Perception factor is known that there is a relationship between nurses' perceptions of the implementation of IPC with p-velue 0.02 .

The results of research to get out of the overall number of nurses who become respondents as many as 34 nurses, inferred types of genital women over many of the men, as many as $92.05 \%$ women. The results of the research describe the kind of sex woman in a nurse who became the respondents of research over many of the men. That more women than men obey authority. ${ }^{14}$ The nurse profession is generally seen as more suitable for women than men, and women are better able to carry out nursing duties. This is also supported which explains that male sex in the nurse's profession is only around $10 \%$. There is an effect of gender with the critical thinking ability of nurses. Characteristics of nurse education level with D3 Nursing education level have the highest number. The results of an analysis of all study respondents found $91.17 \%$ of Nursing Diploma III education.

The results of this study illustrate the nurses who were the respondents in this study the most with D III Nursing education. These results are consistent with the theory that there are still more D3 Nursing in hospitals. BPPSDM-Ministry of Health explains that nurses who work at home sick vertical educated D3 of Nursing as much as $80 \%$. Education shows the ability of someone to complete a job given to him. The higher the nurse's education, the higher the level of compliance in completing work. ${ }^{14}$ The condition of nurse education level in Indonesia is still dominated by D3 Nursing.

Based on the characteristics of age, most of nurses was at the age productive. The average age of nurses who became the respondents in the study is 28.03 years. The results of this study illustrate the average age of 28.03 years at a productive age). the average age of nurses is at an average productive age. Age is one analysis looking at the quality of one's work. A person's age can be seen from their experience and commitment to a job. The maturity of one's age shows one's behavior towards acting and work productivity. $\cdot \frac{15}{}$

The results of other studies suggest that there is no effect of age on a person's performance. research on the effect of reflective supervision with safety compliance on the dangers of biological agents. The study proved that there was no effect of age with patient safety adherence to the dangers of biological agents $(p=0.57)$. This is because the higher the age, the performance will decrease.

The nurse's tenure in this study averaged 6 years. there was no influence of the working period with changes 
in nurse safety behavior $(p=0.92)$. This is also reinforced in, that there is no influence of the work period with the application of patient safety. This contradicts other studies where someone who has a longer work experience gets more knowledge than a new employee. Old employees become role models for new employees to manage the organizational culture. Other studies explaining tenure and satisfaction are positively related to work productivity. ${ }^{14}$

Factors of Knowledge, Attitude, Motivation, and Nurse's Perception of Infrastructure Facilities Before Intervention

The results showed average knowledge of nurses regarding the implementation of the IPC is 11:21 (80.07\%). And it is known that there is a relationship between nurses' knowledge and the implementation of IPC at Hospital X (pv 0.01). Knowledge influences the increase in nurses' compliance in implementing IPC. $\frac{16}{}$ Nurses who are less able or less knowledge in implementing IPC will have an impact on the lack of nurse compliance in implementing IPC. The increase in IPC implementation was strongly influenced by the high knowledge and ability of nurses in implementing IPC. ${ }^{11}$ Training is an effort to increase nurses' knowledge about IPC explained that knowledge contributes to compliance and makes it easier for someone to implement programs and preventive actions that contribute to avoiding work exposure. ${ }^{?}$

The results showed the average attitude of nurses towards the implementation of IPC was 3.05 (25.42\%). In the study, it was found that there was no relationship between nurses' attitudes and IPC implementation (pv 0.51). This is in line with the research of Pancaningrum explaining that there is no meaningful relationship between attitude and the performance of nurses in the prevention of infection. $\frac{16}{}$

The results showed the average motivation of nurses in implementing IPC was 3.05 (61\%). The results showed that there was a relationship between nurses' motivation and IPC implementation at Hospital X (pv 0.04). This is in line with research by Kreitner \& Kinicki, explained that motivation can arouse, manage, maintain and channel a behavior in a person. ${ }^{17}$ Compliance is influenced by the appreciation of others, especially colleagues so that it has a positive impact on the quality of services provided. This is confirmed that motivational factors are related to personal rewards that are directly related to work. ${ }^{14}$

The results showed the average nurse's perception of facilities and infrastructure in implementing IPC was 3.02 $(50.33 \%)$. In this research, it is known that there is a relationship between nurses' perceptions of facilities and infrastructure in implementing IPC (0.02). This is in line with the research of Kirklan, in his research explaining that perceptions of facilities have the highest score that affects compliance. $\frac{18}{}$ Facilities and infrastructure factors that are less supportive greatly affect nurse compliance. the availability of facilities and infrastructure is very supportive in increasing nurse compliance in implementing IPC..$^{11}$ The perceptionof adequate funding also greatly influences the availability of facilities and infrastructure, due to the lack of theese facilities and infrastructure, resulting in the tools used are difficult to reach when nurses want to use it.

Perceptions of the equipment that is less convenient to use also greatly affect the compliance of nurses. For instance, nurses are less comfortable to wear gloves while doing nursing, nurses feel claustrophobic when using masks, nurses feel less suited to handrab used in hand hygiene that often results in skin irritation and dry skin..$^{11}$ Standard operating procedures (SOP) that have been set will be difficult if the required infrastructure is not by the existing SOP. Therefore, the availability of infrastructure is needed to smooth the quality of service.

\section{CONCLUSION}

The results of this study can be concluded that the characteristics of nurse who became the respondents in the study based on the gender was dominated women, the level of educatio was Diploma of Nursing, the average age of nurses was at times productive, and period of work was an average of 6 years. Based on the knowledge factor, it is found that there is not a correlation between knowledge and the implementation of the IPC. The attitude factor has no correlation with the implementation of the IPC. The motivation factor has a relationship with the implementation of IPC. The perception factor towards infrastructure is related to the implementation of IPC. This research is expected to be used as a reference in increasing nurses 'compliance with the implementation of infection prevention and control, especially efforts to increase nurses' knowledge, to motivate nurses and improve the perception of nurses in implementing IPC in hospitals.

\section{REFERENCE}

1. CDC, (2008). Healthcare-Associated Infections (HAIs) https://www.cdc.gov/winnablebattles/report/HAIs.html. di akses october 28, 2019

2. WHO. (2009). Practical guidelines for infection control in health care facilities practical guide. New Delhi: world health organization . Retrieved from 
http://www.wpro.who.int/publications/docs/practical_g uidelines_infection_c ontrol.pdf

3. Rotti, G., \& Sjattar, E. (2014). The Relationship between the Function of the Head of Management and the Implementation of Infection Prevention and Control in the Inpatient Room of the Central General Hospital Prof. R. D Kandou Manado. Health ANN, 4 (1), 69-77. http://doi.org/SSN 2252-5416

4. Sofia, S., Saragih, GN, Rahayu, BMS, \& Alvionia, DW (2014). Room with Nurse Compliance in the Application of Nosocomial Infection Control at Santo Yusup Hospital in Bandung. Indonesian Nursing Journal , 69-78.

5. Haac, B., Rock, C., Harris, A. D., Pineles, L., Stein, D., Scalea, T., ... Thom, K. a. (2017). Hand Hygiene Compliance in the Setting of Trauma Resuscitation. Injury, 48(1), 6-11. http://doi.org/10.1016/j.injury.2016.08.004

6. Öztürk, TC, Tali, A., Topal, T., \& Güneysel, Ö. (2014). The Practice of Emergency Medicine Residents Regarding the Use of Personal Protective Equipment for Protection against Infectious Diseases. The Journal of Academic Emergency Medicine , 13 (80), 176-181. http://doi.org/10.5152/jaem.2013.019

7. Ndejjo, R., Musinguzi, G., Yu, X., Buregyeya, E., Musoke, D., Wang, J., ... Ssempebwa, J. (2015). Occupational Health Hazards among Healthcare Workers in Kampala, Uganda. Journal of Environmental and Public Health , 2015 (9), 9.

8. Tung, C., Chang, C., Ming, J., \& Chao, K. (2014). Occupational Hazards Education for Nursing Staff through Web-Based Learning. International Journal of Environmental Research and Public Health , 11 (13), 13035-13046. http://doi.org/10.3390/ijerph111213035

9. Efstathiou, G., Papastavrou, E., Raftopoulos, V., \& Merkouris, A. (2011). Factors influencing nurses' compliance with Standard Precautions in order to avoid occupational exposure to microorganisms: A focus group study. BMC Nursing, 10 (1), 1. http://doi.org/10.1186/1472-6955-10-1

10. Hutahaean, S., Handiyani, H., \& Gayatri, D. (2018). Implementation of infection prevention and control through strengthening the role and function of the head of room in the hospital. Husada Karya Jaya Nursing Academic Journal, 4 (1), 41-52. Retrieved from http://ejurnal.husadakaryajaya.ac.id/index.php/JAKHKJ /article/viewFile/72/65

11. Halton, K., Hall, L., Gardner, A., MacBeth, D., \& Mitchell, BG (2017). Exploring the context for effective clinical governance in infection control. American Journal of Infection Control , 45 (3), 278283. http://doi.org/10.1016/j.ajic.2016.10.022

12. Darmstadt, GL, Ahmed, a SMNU, Saha, SK, Chowdhury, M. a K. a, Alam, M. a, Khatun, M., ... Santosham, M. (2005). Infection control practices reduce nosocomial infection and mortality in preterm infants in Bangladesh. Journal of Perinatology , 25 (5), 331-335. http://doi.org/10.1038/sj.jp.7211283

13. Pegram A, BJ (2015). Infection prevention and control. Journal of Art \& Science, 29 , 37-42.

14. Robbins, SP, \& Judge, T. a. (2013). Organizational Behavior (15th ed.). New Jersey: Pearson Education.

15. Jeong SY, K. K. (2016). Influencing factors on hand hygiene behavior of nursing students based on theory of planned behavior: A descriptive survey study. Nurse Education Today, 36, 159-164. http://doi.org/10.1016/j.nedt.2015.09.014

16. Pancaningrum. (2011). Factors Affecting the Performance of Implementing Nurses in the Inpatient Room in the Prevention of Nosocomial Infection in Hospitals. Jakarta Hajj 2011, Thesis, University of Indonesia, Depok

17. Kreitner, Robert and Angelo Kinicki. (2014). Organizational Behavior. Issue 9. Book 1. Jakarta: Salemba Empat.

18. Kirkland, Katherine Hayes. 2011. Dissertasion Thesis. Nurses and Standart/Universal Precautions Analysis of Barriers Affecting Strict Compliance. The Faculty of The School of Public Health and Health Services the George Washington. 